УдК 532.529 .5

PhD Granovskiy E., Smalii V.

\title{
MODEL OF SOLID PARTICLE DEPOSITION FROM THE TURBULENT GAS FLOW
}

\begin{abstract}
The deposits of solid particles on the walls of pipeline are the cause of pipeline choking and even rupture accidents in industry each year causing misleading the process intent, destructions, human casualties as well as environmental pollutions. To measure and to manage the risks caused by particles deposition are one of the objectives of modern process safety. The measure of risk means to find a probability of event occurring during some specific duration of time (most often 1 year) and to know the consequences of the event. To be able to find the probability of pipeline choking the dynamic model of particle deposition need to be developed. There are numerous studies of solid particle deposition on the walls of pipeline with turbulent or laminar flows of compressible or incompressible liquids. The model of solid particle deposition from the turbulent gas flow has been proposed and qualitatively verified under this study. The solution of governing equations with applying of finite elements method and numerical analysis has been found. In the basics of the current study the model of particle deposition intensity from the turbulent flow developed by S. K. Beal (1970) has been applied. The model accounts both eddy and Brownian diffusivity factors which are competing with each other depending on particle's size scale and flow properties. A comparison of the model's behaviour with the other particle deposition model has been provided and showed a good qualitative agreement with other studies. The model can be applied in numerical risks analysis (with caution) in the part of time duration calculation which causes the critical increasing of pipeline's resistance. Also finite element method gives the profile of deposits (deposition thickness distribution along the pipe) which can be useful to predict the possible coordinates of the maximum deposition thickness as well as to study the influence of different initial conditions such as particle and fluid properties on the deposition rate and distribution as well as to observe a hydraulic regime in the pipeline.
\end{abstract}

Keywords: numerical analysis, particle deposition, pipeline, turbulent flow, diffusivity

\section{Introduction}

Deposits of hydrocarbons, polymers, wax, hydrates or even sand in a pipeline can cause a damage of industry facilities yearly changing a hydraulic regime of a pipeline, decreasing or even stopping flow rate [1]. As a risk factor the probability of pipeline resistance increasing more than limit mark has been assumed. The probability of pipeline's depositions which cause a significant increasing of pipeline's resistance is connected to the time duration of releases with solid particle contaminations and the expectancy of this type of releases during a time period such as a 1 year as well as duration of the release needed to achieve the increasing of pipeline resistance higher than limit value. To be able to predict a time period of pipeline service under the conditions of solid particles presence in a fluid flow a multiple models and studies have been done which differ in initial/boundary conditions and precisions of the results. Such models vary from simplified empirical types [2], [3], [4] to more sophisticated theories with higher agreement with experimental data [5], [6], [7]. The main idea of the published researches is to account eddy diffusivity and Brownian movement as a deposition force for a particles of different scales. This theory has been implemented in our study and the result obtained is a simplified half-empirical model which predicts the deposition profile along the pipe for a certain moment of time since the flow has been started.

\section{Mathematical description}

The model assumes next considerations:

- a pipe with defined length, constant roughness and various diameter is given;

- the pipe connects inlet and outlet with defined pressures;

- the pressure at the inlet should be more than the pressure at the outlet;

- fractional composition of solid particles by size is defined;

- a mean diameters of each particles fraction are defined;

- particles are spherical;

- gas flow is isothermal;

- gas is ideal;

- gravity could be neglected due the sizes of particles (less than $100 \mu \mathrm{m}$ ) and the velocity of the gas flow (Re greater than 4000);

- fractions concentrations of particles at the inlet of pipe are independent of time.

As shown at figure 1 we have a gas flow containing solid particles which is moving by the pipe from the point with a higher pressure to the point with a lower pressure. On the way of gas flow we can observe a particle deposition on the pipe wall which inflicts a variety of a cross-sectional diameter along the pipe. Pipe is divided on equal elements with length $\Delta \mathrm{x}(\Delta \mathrm{x} \rightarrow 0)$. Each element contains its own concentration of particles, fluid velocity, pipe cross-section diameter, pressure and deposition rate. 


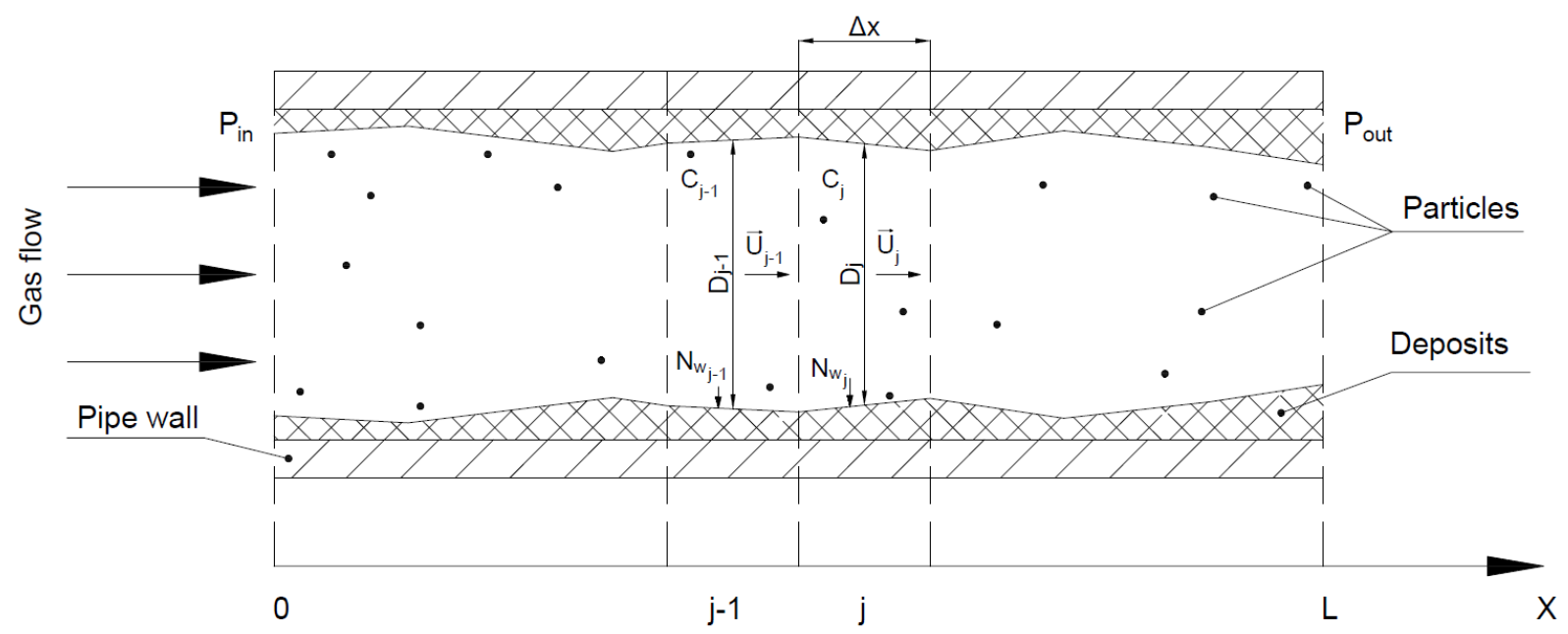

Figure 1 - Schematic depiction of solid particle deposition model from the turbulent gas flow

Assume that we have a number of fractions of the solid particles. Each fraction relates to mean diameter of particle and particles concentration. As well as deposition intensity is a function of particle diameter then the deposition intensities should be calculated separately for each fraction (we assume that particle interaction could be neglected as we consider low particle concentrations in the gas flow). The continuity equation for i-th fraction of solid particles could be described as:

$$
\frac{d N_{j, i}}{d \tau}=F_{j-1} \cdot C_{j-1, i}-F_{j} \cdot C_{j, i}-N_{w_{j, i}} \cdot \pi \cdot D_{\text {pipe }_{j}} \cdot \Delta x
$$

where: $N_{j, i}$ is an amount $[\mathrm{kg}]$ of $\mathrm{i}$-th particles fraction in $\mathrm{j}$-th element; $\tau$ - time [sec]; $F_{j-1}, F_{j}$ - are volume flow rates $\left[\mathrm{m}^{3} / \mathrm{sec}\right]$ of gas flow in j-1-th and j-th elements respectively; $C_{j-1, i}, C_{j, i}-$ are concentrations $\left[\mathrm{kg} / \mathrm{m}^{3}\right]$ of the particles of ith fraction; $N_{w_{j, i}}$ is a deposition intensity $\left[\mathrm{kg} /\left(\mathrm{m}^{2} \cdot \mathrm{sec}\right)\right]$ of the particles of $\mathrm{i}$-th fraction in $\mathrm{j}$-th element; $D_{\text {pipe }}$ is a diameter of pipe (accounting the deposits) in the $\mathrm{j}$-th element; $\Delta x$-is a step-size [m] of element.

For simplification of the problem and accounting relatively high velocity of the gas flow we consider that each time step of solution we observe stationary concentration distribution along the pipe:

$$
\frac{d N_{j, i}}{d \tau}=0
$$

Rewriting eq. (1) accounting eq. (2) gives:

$$
F_{j-1} \cdot C_{j-1, i}-F_{j} \cdot C_{j, i}-N_{w_{j, i}} \cdot \pi \cdot D_{\text {pipe }_{j}} \cdot \Delta x=0
$$

$N_{w_{j, i}}$ could be defined as:

$$
N_{w_{j, i}}=K_{\operatorname{dep}_{j, i}} \cdot C_{j, i}
$$

where: $K_{d e p_{j, i}}$ is an deposition velocity [m/sec] of solid particles of $\mathrm{i}$-th fraction in $\mathrm{j}$-th pipe element.

Eq. (3) and eq. (4) could be used to define a concentration of the i-th particles fraction in the flow which moves to the next element:

$$
C_{j, i}=\frac{F_{j-1} \cdot C_{j-1, i}}{F_{j}+K_{\text {dep }_{j, i}} \cdot \pi \cdot D_{\text {pipe }_{j}} \cdot \Delta x}
$$

To be able to define a diameter variation of the $\mathrm{j}$-th element as a function of time we need to find a total deposition grow speed $[\mathrm{m} / \mathrm{sec}]$ in the $\mathrm{j}$-th element. The total deposition grow speed could be defined as:

$$
U_{w \Sigma_{j}}=\sum_{i=1}^{N} \frac{N_{w_{j, i}}}{\rho_{i}}
$$

where: $N$ is an amount of particle fractions; $N_{w_{j, i}}$ is a deposition intensity $\left[\mathrm{kg} /\left(\mathrm{m}^{2} \cdot \mathrm{sec}\right)\right]$ of the particles of i-th fraction in $\mathrm{j}$-th element; $\rho_{i}$ is a mean density $\left[\mathrm{kg} / \mathrm{m}^{3}\right]$ of the particles of $\mathrm{i}$-th fraction.

Diameter variation as a function of time could be defined as:

Substitution of eq. (6) to eq. (7) gives:

$$
\frac{d D_{\text {pipe }}}{d \tau}=-2 U_{w \Sigma}
$$

$$
\frac{d D_{\text {pipe }_{j}}}{d \tau}=-2 \sum_{i=1}^{N} \frac{N_{w_{j, i}}}{\rho_{i}}
$$

To be able to define the gas flow velocities and pressures in each element of the pipe the Darcy-Weisbach equation could be applied [8]:

$$
K_{j} \frac{\Delta x}{S_{j}} \frac{\rho_{g_{a s_{j}} U_{j}^{2}}}{2}=P_{j-1}-P_{j}
$$


where: $K_{j}$ - is a Darcy-Weisbach friction factor of $\mathrm{j}$-th element; $S_{j}$ - is a cross-section area [m $\left.{ }^{2}\right]$ of the $\mathrm{j}$-th element; $\rho_{\text {gas }}{ }_{j}$ - is a gas density $\left[\mathrm{kg} / \mathrm{m}^{3}\right]$ in the $\mathrm{j}$-th element; $U_{j}-$ is a velocity $[\mathrm{m} / \mathrm{sec}]$ of a gas in the j-th element; $P_{j-1}, P_{j}$ are pressures of $\mathrm{j}$-1-th and $\mathrm{j}$-th elements respectively.

Darcy-Weisbach coefficients could be defined by numerous empirical methods (as well as by using a hydraulic calculation of the pipeline) or by using the Colebrook-White equation [9].

Continuity equation for gas flow could be written as:

$$
U_{j} \cdot \frac{s_{j}}{V_{M_{j}}}=\text { const }
$$

where: $V_{M_{j}}$ is a molar volume $\left[\mathrm{m}^{3} / \mathrm{mol}\right]$ of the gas in the $\mathrm{j}$-th element.

The area of cross-section of the pipe in $j$-th element could be defined as:

$$
S_{j}=\pi \frac{D_{\text {pipe }_{j}}^{2}}{4}
$$

The molar volume of gas could be defined as (assuming gas as ideal):

$$
V_{M_{j}}=\frac{R \cdot T}{P_{\text {avg }}}
$$

where: $R$ is gas constant $[\mathrm{J} /(\mathrm{mol} \cdot \mathrm{K})] ; T$ is a temperature $[\mathrm{K}]$ of gas flow (we assume an isothermal gas flow); $P_{a v g}{ }_{j}-$ is an average pressure of $\mathrm{j}$-th element.

The average pressure of the $\mathrm{j}$-th element could be defined as shown below:

$$
P_{a v g_{j}}=\frac{P_{j-1}+P_{j}}{2}
$$

Equations (9), (10) could be solved numerically using linear algebra methods and graph theory.

The intensity of particle deposition is a complex function of numerous variables and defined by S.K. Beal (1970) [2] as follows:

$$
N_{w_{j, i}}=f\left(e_{\text {pipe }}, D_{\text {pipe }_{j}}, R e_{j}, U_{j}, v_{\text {gas }}, \mu_{\text {gas }_{j}}, \rho_{\text {particle }_{i}}, d_{\text {particle }_{i}}, C_{j, i}, T, p\right)
$$

where: $e_{\text {pipe }}$ is a pipe roughness [m]; $R e_{j}$ is a Reynolds number in j-th element; $v_{\text {gas }}$ is a kinematic viscosity $\left[\mathrm{m}^{2} / \mathrm{sec}\right]$ of gas; $\mu_{\text {gas }_{j}}$ is a dynamic viscosity $[\mathrm{kg} /(\mathrm{m} \cdot \mathrm{sec})]$ of a gas in $\mathrm{j}$-th element; $\rho_{\text {particle }_{i}}$ is a mean density $\left[\mathrm{kg} / \mathrm{m}^{3}\right]$ of the particles of $i$-th fraction; $d_{\text {particle }_{i}}$ is a mean diameter of the particles of $i$-th fraction; $C_{j, i}$ is a concentration $\left[\mathrm{kg} / \mathrm{m}^{3}\right]$ of the particles of $\mathrm{i}$-th fraction in $\mathrm{j}$-th element; $T$ is a gas temperature $[\mathrm{K}] ; \mathrm{p}$ is a probability of adhesion of the particle to the wall of pipe (assumed to be equal to 1).

The probability of the particle adhesion in general depends of restoring force (due the collision between particle and wall), friction force, force of viscosity on small sphere and adhesion force as a function of both particle and wall surfaces' and materials' parameters [3].

Solving equations (5), (8), (9) and (10) accounting the intensity of deposition function (14) gives a dynamics of pipe diameter distribution along the pipe as well as a velocities of gas and pressures for each element.

\section{Results and discussion}

Several numerical simulations have been made in nanoscale and microscale (ranges $2-200 \mathrm{~nm}$ and $0,5-20 \mu \mathrm{m}$ of sizes of particles). Initial conditions are shown in Table 1.

Table 1 - Initial conditions of nanoscale particle simulations

\begin{tabular}{|l|l|l|l|l|l|l|l|l|l|}
\hline $\begin{array}{l}\text { Particle } \\
\text { concent } \\
\text { ration } \\
{\left[\mathrm{kg} / \mathrm{m}^{3}\right]}\end{array}$ & $\begin{array}{l}\text { Fluid } \\
\text { type }\end{array}$ & $\begin{array}{l}\text { Pipe } \\
\text { diameter } \\
{[\mathrm{m}]}\end{array}$ & $\begin{array}{l}\text { Pipe } \\
\text { length } \\
{[\mathrm{m}]}\end{array}$ & $\begin{array}{l}\text { Surface } \\
\text { roughness } \\
{[\mathrm{m}]}\end{array}$ & $\begin{array}{l}\text { Particle } \\
\text { density } \\
{\left[\mathrm{kg} / \mathrm{m}^{3}\right]}\end{array}$ & $\begin{array}{l}\text { Tempe } \\
\text { rature } \\
\text { of air } \\
{[\mathrm{K}]}\end{array}$ & $\begin{array}{l}\text { Inlet/outl } \\
\text { et } \\
\text { pressure } \\
{[\mathrm{Pa}]}\end{array}$ & $\begin{array}{l}\text { Simulation } \\
\text { time }[\mathrm{sec}]\end{array}$ & $\begin{array}{l}\text { Darcy } \\
\text { friction } \\
\text { factor }\end{array}$ \\
\hline 0.006 & air & 0.02 & 30 & 0.0001 & 1200 & 293 & $\begin{array}{l}111235 / 1 \\
01325\end{array}$ & 10000 & 0.01 \\
\hline
\end{tabular}

Fig. 2 displays the deposition thickness distribution along the pipe in condition that all the particles are single-sized (particle size varies from $2 \mathrm{~nm}$ to $200 \mathrm{~nm}$ ). As well as Brownian diffusivity has been implemented in the basis of the model, so nanoparticles can be deposited due Brownian movement. Fig. 1 shows that with increasing of nanoparticles size the deposition rate decreases because of the affinity of nanoparticles to the Brownian deposition [5]. The deposition thickness is more significant at the inlet of the pipe due the higher concentration of nanoparticles and almost equal Reynolds number along the pipe (due the small pressure drop and small Darcy friction factor). 


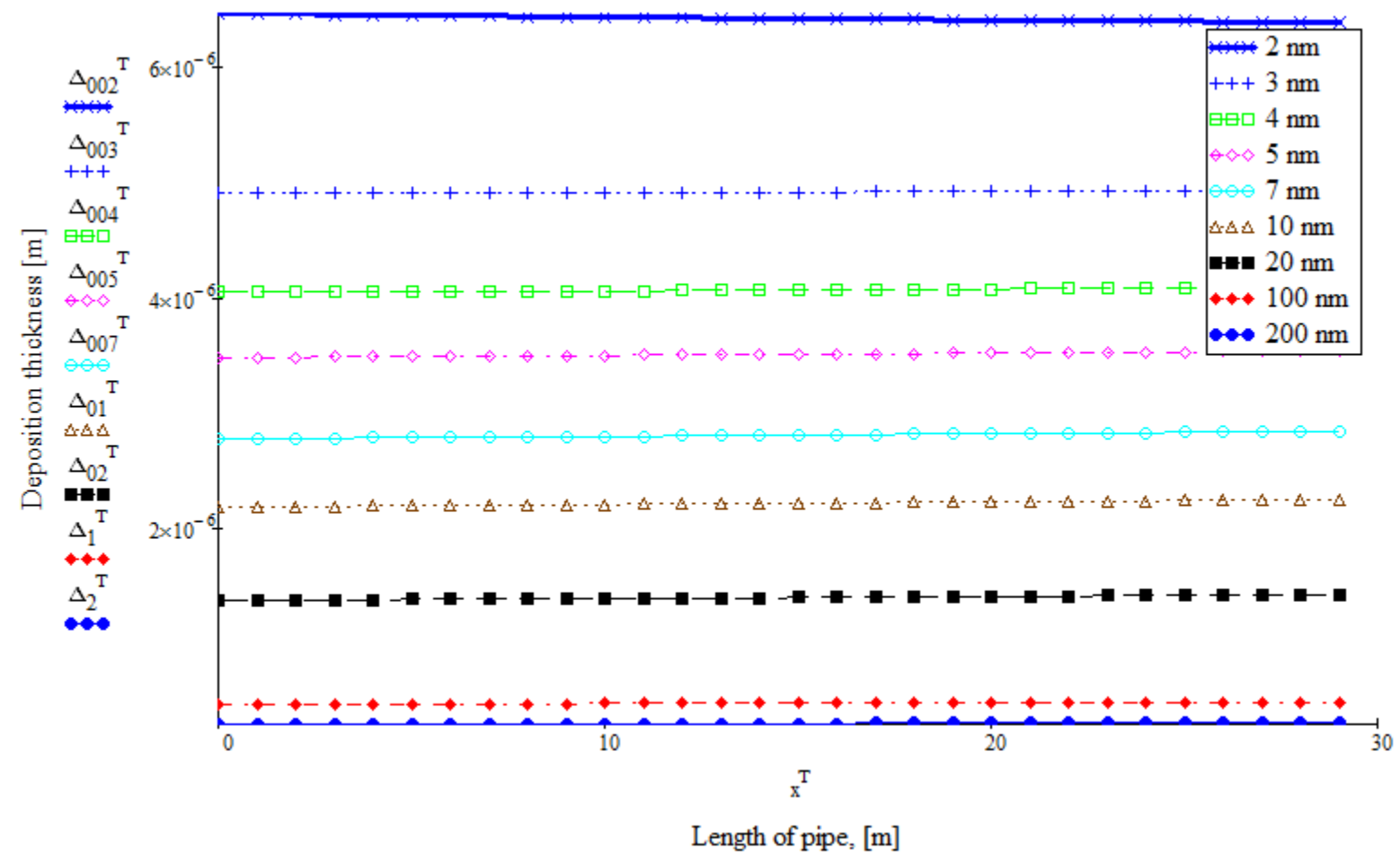

Figure 2 - Deposition thickness distribution of nanoparticles along the axis of the pipe

The opposite phenomena can be observed for micro-scale particles: the decrease of particle size implements increasing of the deposition thickness Fig. 3 (initial conditions are the same as shown in Table 1, particle size range lays between 0.5 and $20 \mu \mathrm{m}$ ). This effect could be explained by the eddy diffusivity mechanism which causes penetration of stopping distance layer by massive particles [2], [10].

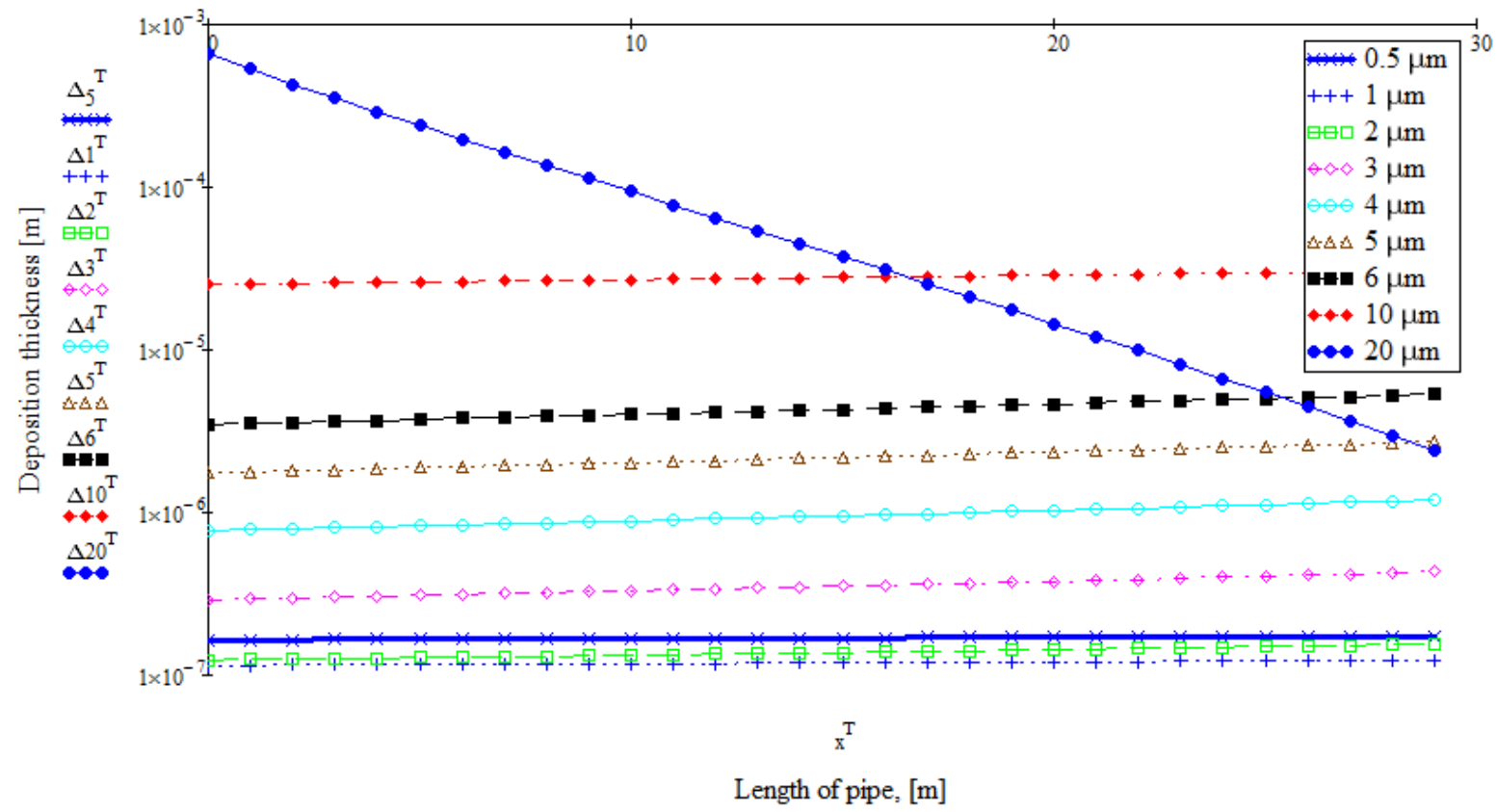

Figure 3 - Deposition thickness distribution of micro-particles along the axis of the pipe

The size of particle and deposition profile relation is in normal qualitative agreement with data presented in [5]. This can be explained by Brownian diffusivity and eddy diffusivity mechanisms implemented in a function of deposition rate calculation [2]. An absence of experimental (or numerical simulation) data cannot approve the model's behavior quantitatively though the model uses simplified method which can be easily applied for solid particles deposition problem.

\section{Conclusions}

The model of solid particle deposition has been developed on the basis of Beal's deposition model for compressible 
fluid flow. This approach covers only turbulent flow (Re over 4000). The model was validated with available published data and qualitative agreement has been observed. A lack of relevant experimental data causes a problem with the quantitative validation. The nanoscale and microscale particles influence on the deposition profiles is observed and correlated with other published research data. The Brownian diffusivity takes place for a particles of nanoscale because of the affinity of nanoparticles to the Brownian deposition. Increasing the size of particles in nanoscale implyies the decreasing of particle deposition rate. On the boundary of nanoscale particle size transition to microscale the local minimum of particle deposition rate has been observed. The cause of this minimum of deposition rate could be described as both non-affinity of particle to Brownian deposition and still insufficient energy of little particle needed to stopping layer penetration. Increasing the size of the particle in microscale the increasing of solid particles deposition rate is following because of increasing of kinetic energy of particle which allows the penetration of stopping layer. So, particle size, turbulence scale, fluid compressibility, temperature and other physical properties such as viscosity and density of the fluid, pipe parameters such as surface roughness, diameter and length are essential in a prediction of deposits profile along the pipe. The model accounts hydrodynamics of fluid flow as a function of pressure difference, fluid properties, deposits profile and pipe parameters. Developed model could be used for prediction of risk in industry where flows with solid particles contamination occur.

Acknowledgements. This work was supported by Scientific Centre of Risks Research "RIZIKON". Special thanks to $\mathrm{PhD}$ S. Kudryavtsev for support on each step of material publishing.

\section{References}

1. Van der Werff A. The Importance of Pipeline Cleaning: Risks, Gains, Benefits, Peace of Mind / AndrÈ van der Werff. // Pipeline Technology 2006 Conference. - 2006.

2. Beal S. K. Deposition of Particles in Turbulent Flow on Channel or Pipe Walls / S. K. Beal. // Nuclear Science and Engineering. - 1970. - №40. - Pg. 1-11.

3. Osajdenie tverdych chastic v laminarnom pogranichnom sloe na ploskoy plastine / [A. I. Kartyshinskii, I. A. Krupenskii, S. V. Tisler et al.]. // TVT. - 2009. - №47. - Pg. 927 - 936.

4. Pouyan Talebizadehsardari, Hassan Rahimzadeh, Goodarz Ahmadi, Kiao Inthavong, Mohammad Mehdi Keshtkar, M.A. Moghimi. Nano-particle deposition in laminar annular pipe flows. Advanced Powder Technology.

5. A new theory for modeling transport and deposition of solid particles in oil and gas wells and pipelines / [P. Talebizadehsardari, E. Khamehchi, S. A. Mousavi-Dehghani et al.]. // International Journal of Heat and Mass Transfer. - 2020. - №152. - Pg. 1-11.

6. Walsh J. K. An Experimental Study of Thermophoretic Deposition of Aerosol Particles in Laminar Tube Flow with Mixed Convection / J. K. Walsh, A. W. Weimer, C. M. Hrenya. // Aerosol Science and Technology. - 2006. - №40. Pg. 178-188.

7. Wang F. J. Pressure gradient and particle adhesion in the pneumatic transport of cohesive fine powders / F. J. Wang, J. X. Zhu, J. M. Beeckmans. // International Journal of Multiphase Flow. - 2000. - №26. - Pg. 245-265.

8. Pumping station design / G. M.Jones, B. E. Bosserman II, R. L. Sanks, G. Tchobanoglous. - Burlington, MA: Butterworth-Heinemann, 2006. - 1261 Pgs. - (3).

9. Clamond D. Efficient resolution of the Colebrook equation / Didier Clamond. // Industrial and engineering chemistry research, American Chemical Society. - 2009. - №48. - Pg. 7-22.

10. Friedlander S. K. Deposition of Suspended Particles from Turbulent Gas Streams / S. K. Friedlander, H. F. Johnstone. // Industrial and engineering chemistry. - 1957. - №47. - Pg. 1151-1156.

Відкладення твердих частинок на стінках трубопроводу є причиною забивки трубопроводу або навіть аварійних розривів трубопроводів у промисловості щороку, щзо спричинює відхилення від иілей процесу, руйнування, людські жертви, а також забруднення навколишнього середовища. Вимірювати та управляти ризиками, спричиненими осадженням частинок, є однією з цілей сучасної промислової безпеки. Міра ризику означає виявлення ймовірності події, щьо відбулася протягом певної тривалості часу (найчастіше 1 рік) $i$ знання наслідків подіі. Щоб мати можливість виявити ймовірність забивки трубопроводу, слід розробити динамічну модель осадження частинок. Існують численні дослідження відкладення твердих частинок на стінках трубопроводу з турбулентними або ламінарними потоками стисливих або нестисливих рідин. Модель осадження твердих частинок із турбулентного потоку газу запропонована та якісно перевірена в рамках цьього дослідження. Знайдено рішення базових рівнянь із застосуванням методу скінченних елементів та чисельного аналізу. В основах поточного дослідження застосована модель інтенсивності осадження частинок з турбулентного потоку, розроблена S. K. Beal (1970). Модель враховує як вихрові, так $і$ броунівські фактори дифузії, які конкурують між собою залежно від масштабу частинок та властивостей потоку. Було проведено порівняння поведінки моделі з іншою моделлю осадження частинок, що показало хорошу якісну узгодженість 3 іншими дослідженнями. Модель може бути застосована для чисельного аналізу ризиків (з обережністю) у частині розрахунку тривалості часу, яка спричиняє критичне збільшення опору трубопроводу. Метод скінченних елементів дає профіль відкладень (розподіл товщини осадження вздовж труби), щзо може бути корисним для прогнозування можливих координат максимальної товщини осадження, а також для вивчення 
впливу різних початкових умов, таких як властивості частинок і рідини, на швидкість утворення осаджень та їх розподіл, i спостерігати за гідродинамічним режимом у трубопроводi.

Ключові слова: чисельний аналіз, осадження частинок, трубопровід, турбулентний потік, дифузія

Отложения твердых частии на стенках трубопровода является причиной забивки трубопровода или даже аварийных разрывов трубопроводов в промышленности ежегодно, что вызывает отклонения от иелей проиесса, разрушения, человеческие жертвы, а также загрязнение окружающей среды. Измерять и управлять рисками, вызванными осаждением частии, является одной из иелей современной промымленной безопасности. Степень риска означает выявление вероятности события, произомедшего в течение определенной продолжительности времени (чаще всего 1 год) и знания последствий данного события. Чтобы выявить вероятность забивки трубопровода, следует разработать динамическую модель осаждения частиц. Существуют многочисленные исследования отложения твердых частич на стенках трубопровода с турбулентными или ламинарными потоками сжимаемых или несжимаемых жидкостей. Модель осаждения твердых частии из турбулентного потока газа предложена и качественно проверена в рамках этого исследования. Найдено решение базовых уравнений с применением метода конечных элементов и численного анализа. В основах текущчего исследования применена модель интенсивности осаждения частиц из турбулентного потока, разработанная S. K. Beal (1970). Модель учитывает как вихревые, так и броуновские факторы диффузии, которые конкурируют между собой в зависимости от масштаба частиц и свойств потока. Было проведено сравнение поведения модели с другой моделью осаждения частии, которое показало хорошую качественную согласованность с другими исследованиями. Модель может быть использована для численного анализа рисков (с осторожностью) в части расчета продолжительности времени, которая вызывает критическое увеличение сопротивления трубопровода. Метод конечных элементов дает профиль отложений (распределение толщины осаждения вдоль трубы), что может быть полезным для прогнозирования возможных координат максимальной толщчины осаждения, а также для изучения влияния различных начальных условий, таких как свойства частии и жидкости, на скорость образования осаждений и их распределение, и наблюдать за гидродинамическим режимом в трубопроводе.

Ключевые слова: численный анализ, осаждение частии, трубопровод, турбулентный поток, коэффициент диффузии.

Грановський Е. О., к.т.н., генеральний директор, ТОВ Науковий центр вивчення ризиків «Різікон»

Смалій В. В., технічний директор, ТОВ Науковий центр вивчення ризиків «Різікон», Східноукраїнський національний університет імені Володимира Даля, jarkfiz@gmail.com

Granovskiy E., PhD, director general, Scientific Center of Risk Investigations "RIZIKON"

Smalii V., chief technical officer, Scientific Center of Risk Investigations "RIZIKON", East-Ukrainian National University named after Vladimir Dahl, jarkfiz@gmail.com 